\title{
The Construction of Women's Image and the Narrative of Nationalism among Face veiled-University Students in West Nusa Tenggara
}

\author{
Atun Wardatun, ${ }^{1}$ Abdul \\ Wahid ${ }^{2}$ \\ 1,2, Universitas Islam Negeri Mataram, \\ Mataram-Indonesia \\ Corresponding Author: Atun Wardatun, \\ email: awardatun@gmail.com, Jl. Pendidikan \\ No. 35, Selaparang, Mataram, Nusa \\ Tenggara Barat 83125
}

\begin{abstract}
This article discusses the image of women and nationalism in the view of 15 female students of the Islamic Religious University (PTKI) in West Nusa Tenggara behind their face-veils (cadar). Methodologically, this study encourages the interpretation of facts from the perspective of the agents by involving the voices of women as subjects who are able to describe their choices and explain their actions responsibly. The choice of female university students as subjects for veil-related research is short among the general trends of research on veils targeting women from militant groups. This research reveals the meaning of the veil as a dynamic and open contestation of women's identity, gender ideology, and nationalism. The dynamics and openness are possible due to the fact that female students are still in the formation phase of identities while veiling existence nowadays more about fashion trends and lifestyle. The dynamics appear in the ambiguity of the self-image of women they hold by placing women as sources of defamation (fitnah) as well as being pillars of the state. Openness is seen in the narrative of their nationalism which is wrapped in a strong inclusive and tolerant attitude, in addition to the tendency of exclusivism and conservatism of a small number of them. The findings of this study contribute to ideas for emancipatory movements such as gender equality and strengthening nationalism. The movements are to continue to be active and more creative in offering alternatives to the establishment of those female students' identity and ideology in a more progressive direction.
\end{abstract}

Keywords: arena of contestation; nationalism; face-veils; ambiguity; ideological struggle; women's image; gender identity

\begin{abstract}
Abstrak: Artikel ini mendiskusikan bagaimana citra perempuan dan paham kebangsaan dalam pandangan 15 mahasiswi Perguruan Tinggi Keagamaan Islam (PTKI) di balik cadar mereka. Secara metodologis, penelitian ini ikut mendorong pemaknaan sebuah fakta dari perspektif pelaku dengan melibatkan suara perempuan sebagai subyek yang mampu menguraikan pilihan dan menjelaskan tindakannya secara bertanggungjawab. Pemilihan mahasiswi PTKI sebagai subyek penelitian terkait cadar masih sangat minim dilakukan di antara kecenderungan umum penelitian tentang cadar yang menyasar perempuan dari kelompok militan. Penelitian ini mengungkap pemaknaan cadar sebagai arena kontestasi identitas dan ideologi yang dinamis dan
\end{abstract}


terbuka. Dinamika dan keterbukaan tersebut dimungkinkan karena faktor internal maupun eksternal. Secara internal, mahasiswi masih berada pada fase pencarian dan pembentukan jati diri. Sementara faktor external adalah kenyataan bahwa cadar saat ini secara umum terarah menjadi sebuah trend fashion dan gaya hidup (religious life style). Dinamika tersebut tampak pada ambiguitas citra diri perempuan yang mereka pegang dengan menempatkan perempuan sebagai sumber fitnah sekaligus sebagai tiang negara. Keterbukaan terlihat pada narasi nasionalisme mereka yang dibaluti sikap inklusif dan toleran yang kuat. Walaupun patut juga dicatat, kecenderungan eksklusivisme dan konservatisme dari sebagian kecil mereka. Temuan penelitian ini memberikan kontribusi ide bagi gerakan emancipatory seperti kesetaraan gender dan penguatan nasionalisme untuk terus aktif dan lebih kreatif menyodorkan alternative bagi pemapanan identitas dan ideologi mereka ke arah yang lebih progresif.

Kata Kunci: arena kontestasi; nasionalisme; cadar; ambiguitas; pergulatanideologi; citra perempuan; identitas gender

\section{A. Introduction}

This article focuses on understanding the construction of gender and the sense of nationalism of face-veiled female university students from Islamic Religious Colleges (PTKI) ${ }^{1}$ in West Nusa Tenggara (NTB).

This topic is crucial because there are general assumptions that identify face-veil (in this article is sometimes mentioned as 'veil') with conservatism, fundamentalism, Islamism, and/or radicalism. Two initial groups are characterized by a rejection of progressive and emancipatory content such as gender equality while the last two are identical with movements that fight for changing Indonesia from five basic principles (Pancasila)-based state into shari'a-based state. In this point, it is essential to focus the research topic on veiled women concerning issues on gender identity and nationalism, led by the following questions: does the veil they wear to act as an explicit message to show women's self-image that is against equality? How do they express their sense of nationalism? Does it lead to attitudes that undermine the five basic principles (Pancasila) of Indonesia? Or is the veil they wear merely a trend and a medium to become better Muslim in religious practice and understanding?

Social phenomenology theory is used as a perspective to see an object/ subject of study with a specific character because this research aims at

1PTKI: Perguruan Tinggi Keagamaan Islam. 
understanding the inner world of face veiled-women. The theory is derived from a perspective on the subjective reality of social life developed by Edmund Husserl and Alfred Schutz, which emphasizes understanding the meaning of life, experience, and internal conditions of the individual. Phenomenology gives a description of the universal structure of the subjective orientation of individuals, and that global structure is the fundamental reality of life/social phenomena. ${ }^{2}$ In phenomenology, meaning and motivation are two important concepts. "Meaning" concerns on how the actor or individual determines what is important to him from the social world, while the "motive" refers to reasons why the actor performs a particular action. ${ }^{3}$

Wearing veils, especially among PTKI female students, is a novel phenomenon that attract the public's and scholar's attention as well. Based on internal observations, at Universitas Islam Negeri Mataram, for example, this phenomenon only emerged in 2014 and was initiated by only a few people. In 2018, the number of those who veiled at the undergraduate (S1) level has reached 72 people spread across five faculties. ${ }^{4}$ Interestingly, face-veiled students have not been seen in post-graduate programs at both the S2 and S3 levels. Does the question then arise whether this veiled phenomenon is a representation of the religious enthusiasm (ghirah) of female students who are in the period of searching for identity and strengthening the Islamic knowledge basis alone? Meanwhile, at Universitas Nahdlatul Wathan (UNW) and the Universitas Nahdlatul Ulama (UNU) there were no veiled students found. At the same time, at Universitas Muhammadiyah Mataram (UMMAT) there were several female students represented by two of 15 informants for this study. ${ }^{5}$

The suspicion of the growing extremist and radical conservatism of the increasingly widespread imposition of veils among students needs to be proven by the data. Otherwise, non-academic allegations may trigger the application of the wrong concept in understanding reality, although it is also worth developing the related assumptions. Among the limited number of studies on

${ }^{2}$ George Ritzer, Contemporary Sociological Theory (New York: Alfred A. Knop, 1988), 205.

${ }^{3}$ Ritzer, 221.

${ }^{4}$ Interview with Dr. Nurul Yaqin, Vice Chancellor 3 of UIN Mataram, October 2018. It was renewed in August 2019 to ask for the latest 2019 data, but not yet available

5Interview with Mulyanah, M.Pd,I, the Chancellor of Universitas Nahdlatul Ulama, Prof. Dr. Fahrurrozy, executive member of Nahdlatul Wathan (NW), and Dr. Arsyad Gani, the Rector of Universitas Muhammadiyah Mataram. 
veiled women, the choice of making students of Islamic university students in West Nusa Tenggara as study subjects has never been done. Therefore this research will fill the literature gaps related to the veil problem not only in its topic, which focuses on the construction of women's self-image and narratives of nationalism but also on the targeted informants and the unique research locus, PTKI in NTB.

In fact, face veil became an arena of identity contestation for women's selfimage and the nationalities of these female students. On the one hand, they see women as a source of defamation (fitnah) that must be guarded and restricted. On the other hand, women are seen as the pillar of state (tiang negara) who determine the good and bad of the nation. This view then metamorphoses into the belief that women's faces and bodies need to be covered. However, that closure must not be the reason to limit the social activities they carry out. From a gender perspective, the above view sees the differences between men and women in a dichotomous and synergistic way. ${ }^{6}$ It is "dichotomous" because it locates women as slander, which can foster a negative stigma against them, giving birth to a derivative of unfair attitudes towards women, for example, their exclusion from the public world. It is "synergistic" because by wearing veil they avoid the consequences of marginalization; rather, the veil should be a medium for them to feel comfortable to socialize with men. Consequently, they can make positive contributions in the public world in line with the potential and educational background they have.

The findings of this study could reverse the prejudice that has been addressed to face-veiled women. There are at least four stereotypes that are often aimed at veiled women and the practice of wearing veils. First, women wearing veils are identical to extremism and terrorism. Second, the veil is part of the Arabization of identity that has been uprooted from the cultural origin of Islamic practices in the archipelago. Third, the veil is a symbol of oppression for women who are not entitled to regulate their bodies. Fourth, the veil is a form of religious fanaticism. The four negative labelling can be simplified into issues of identity that include personal areas (body), religion (fanaticism), nation (arabization) and destructive movements that can harm the principle of peace

${ }^{6}$ Nur Rofi'ah, "Qirā’ah Mubādalah sebagai Syarat Tafsir Agama Adil Gender (Pengantar)," in Qirā'ah Mubādalah: Tafsir Progresif untuk Keadilan Gender dalam Islam, ed. Faqihuddin Abdul Kodir (Yogyakarta: IRCISOD, 2019), 29. 
and friendliness (extremism and terrorism) which are adopted by Islam as the majority religion in Indonesia. ${ }^{7}$ The four stereotypes are not apparent in the findings of this study.

Veil itself has two dimensions, personal choices and ideological demands. Interestingly, these two aspects are dynamic and open. Veil can be questioned and open for debates and critical discussions. Half of the informants, 7 out of 15 people, even still open the opportunity to quit the veil someday if the more compulsory interests require. For example, if they have to choose between veiling, which is sunnah (volunteer choice) and obeying parents which is wäjib (mandatory) when parents disagree with their veiled choices. As a dynamic arena of contestation, the next direction of the veil whether to lead them to a conservative understanding, fundamentalist, and even radical Islamist or to another spectrum: modernist, progressive, liberal and emancipatory, really depends on the religious literacy style that is presented creatively, intensely, and interestingly in front of them. In the middle of vacancy (kehampaan) they experience. They need what is called an "anchor of life". In the transition period of their shift from a minimal understanding of religion to their version of Islam, there was an ideological vacancy that was soon filled by a pattern of understanding that was served and contained certainty. ${ }^{8}$ The weakness of moderate Islam and tertiary institutions for them is the fact that they both provide more alternative to understanding rather than specific answers for their religious quests.

Nisa sees that conservative groups are a minority, but they speak louder mainly because of the mastery of various online media (polymedia). The use of creative and active online media (polymedia events) together with patriarchalism adopted by conservative groups makes them more acceptable to the public because their views are in line with cultural expectations that have been built. ${ }^{9}$ Although progressive groups are actually supported by the largest social organizations in Indonesia, namely Nahdlatul Ulama (NU) and Muhammadiyah, their thoughts are considered to be eccentric by the public and the

\footnotetext{
${ }^{7}$ Eva Fahrun Nisa, "Embodying the True Islam: Face Veiled-Women in Contemporary Indonesia” (Ph.D Thesis. Australian National Univertsity, 2011), https://doi.org/10.25911/ 5d7788f8e8499.

8Ruhaini Dzuhayatin, "Feminism, Religious Moderation, and Radicalism," in The First Annual Conference on Gender and Social Movement (ACGSM) (Jakarta: UIN Syarif Hidayatullah, 2019).

${ }^{9} \mathrm{Nisa}$, Embodying the True Islam.
} 
distribution of discourse through online media or so-called polymedia events is less mastered. By using the case of KUPI ${ }^{10}$ (the Female Ulama Conference in Indonesia) which is an example of progressive women's group movements and GEMAR $^{11}$ (the Movement to Cover Aurat) and hijrah calls from conservative groups, Nisa explained:

Women of KUPI, and indeed most Muslim women, remain the silent majority in building polymedia events to voice their understanding of the position of women. On the contrary, the smaller number of Islamists and other conservative women have been known for their zeal in propagating their understandings of Islam, in particular through their ability to create polymedia events to enable their voices to reach a broader audience. ${ }^{12}$

The silent majority, who need to be 'persuaded' in a creative and friendly way for the direction of religious life and diversity in the Indonesian unity (NKRI) ${ }^{13}$ frame, becomes an arena of contestation for both parties.

Furthermore, this research also reveals that this veil is a religious lifestyle. As a lifestyle, the religious literacy that lies behind it tends to be partial and instant because it depends on trends and is rooted in Islamic populism. At this point, the veil becomes an arena of contestation between accepting modernism through technological devices, such as the internet and social media, that enables them to absorb religious teachings more easily. However, they at the same time, also reject the consequences of modernization, which is seen more as a means of ideological imperialism and war of thought (ghazw al-fikr). Modernization is also seen as a root for sexual freedom and moral degradation. In response to this, among others, they chose to veil to suppress the negative effects of globalization, which is, in their opinion, the logical consequences of modernization.

The face-veiled female students are actually from a neutral religious and political position without affiliation and closeness to specific social-religious or political organizations. They are also mostly from ordinary families who are not recognized as religious 2030 or fanatics. Most of them studied at public schools and then entered the UIN Mataram or Universitas Muhammadiyah Mataram and found themselves in a milieu that was more religious and different from

\footnotetext{
${ }^{10} \mathrm{KUPI}$ : Konferensi Ulama Perempuan Indonesia.

${ }^{11}$ GEMAR: Gerakan Menutup Aurat.

${ }^{12} \mathrm{Nisa}$, Embodying the True Islam, 8.

${ }^{13}$ NKRI: Negara Kesatuan Republik Indonesia.
} 
what they had experienced before. Their religious spirit emerged, which was partly recognized as having grown its seeds at the end of its middle school years. They then look back to the past and realize how many mistakes they have made due to their ignorance. Uniquely, they deepen their understanding of religion, especially how to become a better Muslim woman from studies outside the campus, for example through studies of the Hijaber Community, the call for Tahajjud Community, the Hijab Syar'i Community, the Niqab Squad and the BMIC (back to Muslim identity community).

Meanwhile, Islamic religious institutions of higher education, both public and private, are not only as a tank of thought or a place for the development of Islamic religious scholarship, on the one hand, but also as a practical religious barometer, on the other. The institution is a representation of a culture of Islamic society. What is seen as a religious practice among the academic community can also be read as a sign of the dynamics of thought and style of Islamic studies developed in it. If the veil is seen as part of the process of Arabization, fanaticism, and even conservatism, which leads to radicalism, then in-depth research on the locus of Islamic higher education becomes very important. This is merely considering that Islamic tertiary institutions are considered as bearers of "Islam Nusantara" with moderate character (neomodernism). Islam that pays attention to the context of local culture upholds nationalism and carries a tolerance for Indonesia's diversity

The phenomenon of the veiled female student indeed led to serious discussion, especially among lecturers, especially in relation to the tendency for "conservative turn," in Martin Van Bruinessen's term. ${ }^{14}$ Behind the decision of the Chancellor of UIN Sunan Kalijaga Yogyakarta, who wanted to organize veiled female students in the campus, for example, revealed allegations of a systematic movement that wanted to change the basis of state philosophy from Pancasila to Islam. ${ }^{15}$ So the veil is assumed as more than identity and not just part of the transnationalism movement as a logical consequence of globalization. There is another hidden agenda behind the veil that is to undermine the sense of nationalism, which threatens the unity of the Republic of Indonesia (NKRI).

\footnotetext{
${ }^{14}$ Martin van Bruinessen, "Introduction: Contemporary Developments in Indonesian Islam and the 'Conservative Turn' of the Early Twenty-First Century," in Contemporary Developments in Indonesian Islam: Explaining the Conservative Turn (Singapore: Iseas, 2013), 1-20.

${ }^{15}$ Imam Syafii, "Di Balik Cadar Ada Radikalisme," Alif.Id, March 8, 2018, https://alifi.id/read/muhammad-syafii/di-balik-cadar-ada-radikalisme-b207541p/.
} 
Bruinessen saw that strengthening conservatism was a new development of Indonesian Islam that began after the fall of Suharto even though conservatism had been in Indonesia for a long time. In the introduction to the book "Contemporary Developments in Indonesian Islam: Explaining the Conservative Turn," he explains two main factors fostering this conservatism. First, the strengthening of democracy that allows freedom of expression for conservative, fundamentalism, and even radical groups. This internal factor is also supported by the second factor which is more external, namely the emergence of transnational Islam which more or less succeeded in changing the colour of Islam which had been inscribed in advance by the two largest religious social organizations in Indonesia namely $\mathrm{NU}$ and Muhammadiyah as moderate and compromising Islam. As a result, international perceptions of Indonesian Islam drastically changed from 'the smiling face' to an unfriendly one.

As a starting point to address the overlapping assumptions over whether the veil is identical to a conservative view or part of Islamic fundamentalism and even leads to radicalism, this research bases the typology of the Islamic groups on the definition offered by van Bruinessen that distinguishes between conservatism, fundamentalism and Islamism. According to him, "conservative" is the group that adheres to interpretation based on established doctrines and social rules while rejecting reinterpretations by modernists, liberals, and progressives. They usually disagree on the issue of gender equality and those who question the authority of established religious interpretations. They resist the hermeneutical approach to religious texts. This group may exist in the traditionalist $\mathrm{NU}$ or reformist Muhammadiyah, together with liberals and progressives. While "fundamentalists" are those who really base their religious understanding on literal and rigid interpretations of the main sources of Islamic teachings, namely the Qur'an and the Hadith. This group is the same as conservatives in rejecting hermeneutic interpretations and movements that defend minority rights. However, they both can argue in seeing some established teaching practices if there is absolutely no basis in the Qur'an and the Hadith. Whereas Islamists are those, who see Islam as having a systematic and final political system, and therefore, they promote Islam to be the basis of the state. ${ }^{16}$

\footnotetext{
16Bruinessen, "Introduction: Contemporary Developments in Indonesian Islam and the 'Conservative Turn' of the Early Twenty-First Century"; Al-Chaidar, "Konservatisme Islam di Indonesia (Antara Fundamentalisme dan Radikalisme)," Serambinews.Com, May 21, 2018, https://aceh.tribunnews.com/2018/05/21/konservatisme-islam-di-indonesia-antarafundamentalisme-dan-radikalisme?page $=2$.
} 
In his writings, Bruinessen did not give a specific meaning about radicalism. Still, he also explained that Salafism, which tends to be conservative and fundamental, affects almost all radical movements and organizations in Solo, Central Java. So "radicalism" in this paper means more as a violent way, which may be taken by the groups mentioned above to fight for and maintain the values and beliefs they profess.

This research found that NKRI and Pancasila are still the beautiful scenery behind the veils of these female students. There is a seed of Islamism that appears in a small part of them, for example, by saying that Indonesia will be better if it is based on Islamic law, but in general, Pancasila and tolerance are still the general narratives of the nationalities they profess.

This research is related to the meaning of specific actions and experiences that have a basis in the subjective structure. Therefore, it uses a post-positivist paradigm that sees that reality can be formed by subjective experience.

The breakdown of the paradigm in this study was revealed to be two ways of working, namely the phenomenology ${ }^{17}$ and feminist research methods. ${ }^{18}$ That is because phenomenology as a method is an attempt to describe the basic foundation of human experience by looking at what behind that experience ${ }^{19}$ and how that experience is interpreted. ${ }^{20}$ With this paradigm, the use of veils among PTKI female students is seen as a social action that has a personal dimension, in the form of motives and meanings that are subjective, and social dimensions which interdependently form and shape social values. ${ }^{21}$

Meanwhile, listening to the experience of face veiled-women accommodate feminist research methods that hold the principle that social life is not only shaped by the experience of some of the world's population, which incidentally is men, but each individual's voice is meaningful including women's voices. $^{22}$

\footnotetext{
${ }^{17}$ John W. Creswell, Research Design: Qualitative and Quantitative Approach (New Delhi: Sage Publications, 1994). 1992).

${ }^{18}$ Shulamith Reinharz, Feminist Methods in Social Research (Oxford: Oxford University Press,

${ }^{19}$ E. C. Cuff et al., Perspectives in Sociology (London: Routledge, 2015), https://doi.org/10.4324/ 9781315761053.

${ }^{20}$ Jonathan A. Smith, Qualitative Psychology: A Practical Guide to Research Method (Los Angeles: Sage Publications, 2009), 11.

${ }^{21}$ Yvonna S. Lyncoln and Egon G. Guba, Naturalistic Inquiry (London: Sage Publications, 1985).

22Reinharz, Feminist Methods in Social Research.
} 
The research which inform this article, takes place in West Nusa Tenggara (NTB) by selecting students from the only state islamic religious university, Univeritas Islam Negeri Mataram, and three private PTKI affiliated to socioreligious organizations namely UNU (Universitas Nahdlatul Ulama), UNW (Universitas Nahdhatul Wathan) and UMMAT (Universitas Muhammadiyah Mataram). It turned out that there were no veiled female students (not allowed) at UNU and UNW, so then the data collections were only focused on UIN and UMMAT.

Actually, 70 questionnaires were distributed, but only 50 female students returned, 45 from UIN Mataram and 10 from Muhammadiyah University. The difference in number is because students of UIN Mataram are more easily accessible. Of the 50 respondents, 15 people became informants for in-depth interviews. Besides, they were also gathered in the WhatsApp group, so researchers could observe their discussions and even WA profile pictures to complement primary data obtained.

\section{B. Results and Discussion}

\section{Veiled Women: Between Stigma and Reality}

The statement made by Nisa that research on veiled women in Indonesia is limited is still proven to be true. She even claimed that her study focusing on veiled women from two militant organizations in Indonesia was the first and only up to 2011.23 However, some of the reviews below have built the foundation for a dynamic understanding of veiled women. In general, they uncover stigma which identifies veiled women as part of forbidden movements such as radicalism and Islamism. In reality, a veil is a tool for them to assert identity, negotiate roles, and represent liberation. Although it should be noted, other nuances take place among them, such as exclusivity and truth claims.

In the previous research, there are similarities in the subject of veiled female research, namely targeting women who are militant groups even though they use different terms such as fundamentalist, extremist, terrorist, and Salafy. Following Nisa's study above, the Rumah Kitab Team, consisting of five researchers, interviewed twenty women who were categorized as active and/or former members of the Islamic fundamentalist movement. Although it is not clearly stated in the profiles of the women studied, the research report

\footnotetext{
${ }^{23}$ Nisa, Embodying the True Islam.
} 
which has been published as a book entitled "Kesaksian Para Pengabdi: Kajian tentang Perempuan dan Fundamentalisme di Indonesia" (The Testimony of Servants: Studies on Women and Fundamentalism in Indonesia) chose a photo of veiled women as its front cover. It can be assumed that most, if not all, women are veiled or have used them. This research reveals the motives for joining the fundamentalist Islamic movements and the role of these women in the organizations. ${ }^{24}$

The depiction of veiled women related to extremist and terrorist movements is also seen in research targeting the fictional book by Abidah el Khalaqy entitled "Akulah Istri Teroris (I am the Terrorist Wife)" by Khoiroh and Chakim. They analyzed the power of veiled women's discourse in the novel and revealed their stigmatized acting capacities as terrorist wives to be strong and assertive. Through this discourse analysis, Khoiroh and Chakim see that the image of veiled women in this fictional work is a representation of stigmatization that occurs in social reality. ${ }^{25}$

Wahib in his research on the concept of individual piety for Salafy groups in Indonesia revealed that the use of the veil among Salafy women was an expression of individual piety and the formation of a new identity. This distinctive identity aims to create a boundary for their internal group while simultaneously rejecting westernization that opens women's body and Muslim traditionalists who 'only' wear the hijab. So the veil has a dual function, bringing these women closer to fellow Salafy communities with similar identities but also alienating them from other Muslim groups because they feel different. ${ }^{26}$

Correspondingly, through a research setting in Cairo, Egypt, on working women who wear the hijab, MacLeod saw that it was accommodating (an acquiescence) to women's dress norms while protesting (a resistance) to cultural expectations of women's domestication that the place of women is at home. For them, hijab is not the only a trend of fashion but also representing the notion of liberating values. This group of women works because economic

\footnotetext{
${ }^{24}$ Lies Marcoes-Natsir, Kesaksian Para Pengabdi: Kajian tentang Perempuan dan Fundamentalisme di Indonesia (Jakarta: Rumah Kitab, 2014).

${ }^{25}$ Lailatul Khoiroh and Sulkhan Chakim, "Kuasa Perempuan Bercadar dalam Novel Akulah Istri Teroris Karya Abidah El Khalieqy (Analisis Wacana Teun A. Van Dijk)," Komunika: Jurnal Dakwah dan Komunikasi 10, no. 2 (1970): 292-309, https://doi.org/10.24090/komunika.v10i2.950.

${ }^{26}$ Ahmad Bunyan Wahib, "Being Pious among Indonesian Salafists," Al-Jami'ah: Journal of Islamic Studies 55, no. 1 (2017): 1-26, https://doi.org/10.14421/ajis.2017.551.1-26.
} 
conditions require them to make money, not only as a form of self-expression. They are encouraged to wear the hijab as a form of struggle against the value of patriarchy while sending a message to the public that they are women who have dignity and can protect themselves. ${ }^{27}$

MacLeod's theory is also used by Yuyun Sunesti, et.al to see a group of hijab-niqabi women in Surakarta who join the Salafy group and are categorized as conservative group. According to Yuyun, etal this millennial hijaber uses the niqab not merely as a way and reason for them to follow the Salafy group's way of life, for example, by not using cosmetics. In fact, at the same time they negotiate Salafy practices and views and apply their agency to pursue their goals and express personal preferences. ${ }^{28}$

It seems that the phenomenon of veiled women in tertiary institutions has not become a research topic until the Chancellor Letter of Universitas Sunan Kalijaga No. 1301/Un02/R/AK.00.3/02/2018 in February 2018 on the guidance of veiled students. The letter not only caused controversy but also triggered academics to research the phenomenon. Toha Andiko, in his writings about the application of the principle of sadd al-dhari'ah (prevention) in the veil prohibition in college, studied the background of the action which was triggered by the appearance of a veiled female student photo holding the flag of one of the banned organizations in Indonesia.29 Andiko reviewed the views of the four Islamic scholars (madhāhib) on the use of the veil and then applied the principle of sadd al-dhari'ah, which prioritizes prevention if a particular act is suspected to cause harm. He concluded that the ban was not an attempt to limit the use of the veil but instead as a way to avoid the negative consequences of wearing the veil. ${ }^{30}$

This article reinforces the statement that the negative image of veiled women is based more on stigma than on reality. Instead of being trapped in radicalism, the veiled female student identified herself more with being in a

\footnotetext{
${ }^{27}$ Arlene Elowe MacLeod, Accommodating Protest: Working Women, the New Veiling, and Change in Cairo (New York: Columbia University Press, 1991).

${ }^{28}$ Yuyun Sunesti, Noorhaidi Hasan, and Muhammad Najib Azca, "Young Salafi-Niqabi and Hijrah: Agency and Identity Negotiation," Indonesian Journal of Islam and Muslim Societies 8, no. 2 (2018): 173-98, https://doi.org/10.18326/ijims.v8i2.173-198.

${ }^{29}$ Toha Andiko, "Larangan Bercadar di Perguruan Tinggi Perspektif Sadd al-Dzarîah," Madania 22, no. 1 (July 2018): 113-30, https://doi.org/10.29300/madania.v22i1.993.

${ }^{30}$ Andiko.
} 
Muslim käffah (better and perfect Muslim) while at the same time looking positively at Indonesia and its democratic system. They can, in some parts of their thinking, be identified with Salafy-conservative groups but should not be rashly drawn into the vortex of Islamists who want to pry the basis of the state. Yet, it should be noted that the possibility of affiliating with the last group could have happened if their strong desire to improve themselves by following studies off campus was more intense to be welcomed by the group who were known to be more aggressive and creative in gaining followers. In other words, the personal self-image and ideology underlying them are still very dynamic and open. This character can be seen as an opportunity for universities as academic institutions and civil society as moderate movements to dialogue and stimulate their critical thinking so that the veil becomes a more productive symbol in the context of the emancipatory movement and the strengthening of Indonesia as a state and nation.

\section{Women's Self-Image and the Struggle of Ideology}

\section{Women's Self-Image: Women are Slander but a Pillar of State}

The imposition of veils is a complex phenomenon that must be seen in its internal structure. Reflecting on the study of the veil by Juneman, the complexity of the veil phenomenon can be seen from two representative sides. Psychologically, the use of a veil is subjective, dynamic, and creative in relation to space, time, and experience, meaning that it is "practical" as needed. But there are also potential aspects that are essential and "ideological." In the case of the veil, ideological potential refers to symbolic resistance, which grows along with the state's repression and discrimination against certain practices or cultures that develop in society. ${ }^{31}$ In the use of the veil among PTKI female students, the personal and ideological aspects interact with each other. Personally, there are specific meanings behind the decision to wear a hijab, for example, becoming a better Muslim woman. This meaning also starts from an ideology that is formed from a popular view of women as slander. However, it must be noted that ideology is still dynamic. The age of the informants who are still in the formative years allows them to continue processing. The most obvious indication is the

\footnotetext{
31Juneman, Psychology of Fashion; Fenomena Perempuan (Melepas) Jilbab (Yogyakarta: LKiS Pelangi Aksara, 2010), 11.
} 
recognition of $45 \%$ of those who are willing to take the veil off at any time when faced with other reasons, including a conflict with parents, work requires, a future spouse does not allow, and necessities for a photo diploma.

This process will be influenced by religious literacy and general trends. If these two aspects can be obtained from moderate progressive groups, it is still possible for them to continue to have dialectics and form a more emancipatory ideology about women and nationality. Religious literacy referred to here is more in the sense of recitation that is heard than the book being read. The narration that they have access to is through social media so that the names of preachers and idol figures are those who master the media of contemporary preaching as well as famous artists and celebrities such as Felix Siaw, Adi Hidayat, Pipik Dian Irawati, and Wardah Maulina.

In principle, all informants see that women are slander leading to the circumstance of ignorance and unrest. The whole body of a woman, especially her face, is perceived as a source of defamation. This ignorance stems from the attraction of the opposite sex to the face of women because seeing it then leads to unkind thoughts such as being compelled to imagine and then dare to tease. Furthermore, there will be a free relationship and lead to other negative consequences. And this, of course, will adversely affect social life in the nation and state.

Furthermore, women are a mirror of the goodness of a country, so women must behave as well. One of them said "what can be done even if only partially first, then do it." Fatma said:

The country can advance because of women. Increasingly, everything is open now, and there is nothing that can be covered from women. Women should cover their body for their own needs, that is to guard their glory. ${ }^{32}$

As Muslim women who are in the process of being better than they were before, they experience struggles involving various thoughts or ideas. The accumulation of those leads them to the decision to wear the veil or maintain it no matter how many obstacles they face.

\footnotetext{
${ }^{32}$ Interview with Fatma L., female student of Universitas Muhammadiyah Mataram, April 26, 2019.
} 
The Construction of Women's Image and The Narrative of Nationalism ....

Table 1.

Reason of Wearing Veils and Construction of Self-Image

\begin{tabular}{ll}
\hline Reasons of Wearing Veils & Construction of Self-Image \\
\hline $\begin{array}{ll}\text { - Make amends for the past } \\
\text { - Towards a better Islam }\end{array}$ & $\begin{array}{l}\text { Willing and always looking for } \\
\text { opportunities to transform for the } \\
\text { better }\end{array}$ \\
\hline - Save parents not to sin & $\begin{array}{l}\text { Being able to be a factor of kindness } \\
\text { for others }\end{array}$ \\
- Selps men to valuewomen & $\begin{array}{l}\text { Having the ability to make yourself } \\
\text { - Kempowered and can fight for it } \\
\text { bad things }\end{array}$ \\
$\begin{array}{l}\text { - Take care of themselves because } \\
\text { they are far from parents. }\end{array}$ & $\begin{array}{l}\text { Make women more valued } \\
\text { - Imitate the wife of the Prophet } \\
\text { Provide inspiration for other }\end{array}$ \\
\hline
\end{tabular}

Specifically, the reasons they put forward as the basis for wearing the veil can be seen in Table 1. That reason also reveals how they construct their selfimage as Muslim women. Based on four dimensions of wearing veils in El Guindi's study, namely material, space, communication, and religion, the veil in the eyes of the students emphasizes more on the dimensions of communication but with different meanings. The material aspect of the veil is the covering of particular body parts, while the space dimension refers to physical space. The communication dimension emphasizes the meaning of concealment (privacy), while the religious dimension is still hypothetical because symbolic identities and intrinsic aspects are not always coherent. ${ }^{33}$

The communication dimension of the veil for the informants in this research is actually "not hiding from social life" even though they also still have privacy, but rather as a marker or reminder so that they become better Muslim and communicate that goodness symbolizing their determination to others. The

${ }^{33}$ Fadwa El Guindi, Jilbab: Antara Kesalehan, Kesopanan, dan Perlawanan, trans. Mujiburrahman (Jakarta: Serambi, 2004). 
religious dimension is very marginal, especially since all of them consider the veil is not an obligation but a choice, not a goal but a media. This view has implications for how they see people who are not veiled. Because it is not mandatory, veiling is a choice to be better. It should not force others to veil as they must not negatively look at veiled people.

Don't look at people by their appearance; look them first from inside. Approach them, that's how they are. Not because they are veiled you think, you are inferior to them. You must know that the veil is not sending a message that we want to be an angel, we are human beings, but we are trying to be better than before. ${ }^{34}$

Furthermore, they also said that the veil is not a measure of religiosity and levels of faith. All aspects must be considered so that someone can be identified as being religious. Hearts and intentions need to be straightened. But the veil pushes for better ethics. By being accused of the various stigma behind the veil, such as self-righteousness, terrorism, radicalism, then they need to improve their attitude in order to show good behavior to those who accuse.

\section{Women's Social Activity: Free in Boundaries}

A further consequence of their view of women as slander is that they believe that veiling provides limits as well as freedom. The "boundary" here is more of a symbolic dimension that protects both men and themselves. While "free" means that the veil is a prerequisite for having the freedom to do things that represent their potential, interests, and talents, although in some cases, they have to share space with men. As stated by one of the informants as follow:

I initially used a mask. The mask covers the nose and mouth from dust. People use masks because they protect themselves from dust allergies. If the room is clean, you don't need to wear a mask. I thought for a long time, and the same thing can be applied to the veil. The woman's face is a beauty; this beauty must be hidden, not revealed so as not to tease. Let women not be blamed. Well, if it's closed, it can't be seen and it's okay, to work with men. They also can't see. So, you can't be blamed if anything happens. So, it's free to work even if it's in a shared office. As long as you don't get too close. ${ }^{35}$

They also view social activities to be carried out wholeheartedly by women as well as being housewives and educators for their children. In terms of the dichotomy of public and domestic space, they still place themselves as 2019.

${ }^{34}$ Interview with A. Murniati, female student of Universitas Islam Negeri Mataram, April 23,

${ }^{35}$ Interview with J. Aini, female student of Universitas Islam Negeri Mataram, April 25, 2019. 
those who have multi-burden compared to men. Interestingly, they see that being a housewife is part of an indirect social activity because supporting husbands who work outside the home is also a rewarding field.

Most of them still hold an essentialist view, seeing the role of women as the main housewife and their education ends in a domestic career. They put the household as the smallest unit of national and state life. For example, it can be seen in the Facebook status of one of the informants:

Women with high education are not to compete with men. They only want to prepare themselves to be educators that can produce shining generations. Talking about women means talking about the problem of national civilization, about the future of the nation. Women are the womb of a civilization who act as a benchmark of this nation. If a woman is smart, then the generation that she gives birth to is also smart. Then if you don't give women the right to be educated, then where do you want to take this country? And what is the future of this country? \#Stop_Intimidation! \#StopDiscrimination! ${ }^{36}$

In further discussions with them, they have the awareness to reject discrimination and intimidation that women usually experience. For them the opportunity to go on to tertiary education (university) should provide more opportunities to take part in developing this nation. If there is a formal job that requires them to take the veil off, some of them are willing to do so. Some want to be consistent with their veil by finding another job that can accept them wearing a veil.

\section{Women's Socialization Ethics: Maintaining Privacy, Attracting Attention}

There are implicit exclusivism and truth claims from their answers about the value of the veil. For example, with the term: "wrapped goods in storefronts are more expensive than openly displayed goods." For them, women's bodies have clear privacy limits.

Interestingly, they also realize that with veils, they basically attract the attention of many parties, both negative attention and positive ones. Some suffer from accusations with a bad stereotype and even admit that they have been spat on. While some others feel that they are increasingly valued, considered to be exist, and their opinions are heard. There are also those who feel their friends are more comfortable hanging out with them after veiling.

\footnotetext{
${ }^{36}$ Quoted from Facebook posting by Lana F., female student of Universitas Islam Negeri Mataram, November 15, 2018.
} 
Initially, I used the veil for a very simple reason. Once I came home from campus walking then poked by people from motorbikes on sensitive body parts. I was crying, I felt like invaluable and becoming a sexual object. I then started wearing masks before finally wearing the veil. ${ }^{37}$

After I wear the veil I feel my life is better. I am often seen, like in my class, I used to be just an ordinary student who did not get too much attention even though I explain this, this, and that. But after veiling, thank God, my classmates and lecturers think I am capable. ${ }^{38}$

\section{The struggle of ideology: Rejecting Modernization, Utilizing Technology}

This veiled student understands religion as a guide to life or principles that can lead them to goodness and guard against bad things. Their religious narrative is typical, that life today is full of challenges brought about by materialism and modernism's way of thinking. Humans have come a long way and did not realize they have been lost. When one day, there is a call to return to the right path, only a small group who follow it while the majority is ignorant. Even this former group is referred to as "al-ghuraba," a small group that looks strange, but they are the ones who win. This positional awareness seems to be an essential part of their religious understanding and is one of the motivating factors that allow them to survive wearing veils even though the public considers them "strange".

They also experience a gradual process in interpreting the veil as a selfimage or identity. Ati, for example, initially did not realize that her current condition (veiled) was something that she wanted, but it is in the best sense for herself at this time. For her, wearing a veil is not primarily to distinguish herself from others or become the mere identity, but rather to protect her attitude from moral degradation caused by modernization.

I did not expect to be in a position like this (veiled). In the past, I even hated people who were veiled. It turns out that what I think at that time was not true. Now I feel that wearing a veil is good. I am more comfortable practicing my religion. I think at this time women are suitable to use the veil, because women are slander. 39

Being an ideal Muslim woman, according to religious norms, is their dream to comfort themselves and others around them. They understand their

\footnotetext{
${ }^{37}$ Interview with Hurna S., female student of Universitas Muhammadiyah Mataram, May 2, 2019.

38Interview with Lily H., female student of Universitas Islam Negeri Mataram, April 26, 2019.

${ }^{39}$ Interview with A. Murniati., female student of Universitas Islam Negeri Mataram, April 25, 2019.
} 
religion by listening to popular preachers through online media and offline studies that were initially invited by friends. They do not become aware of the ideological tendencies of discourse that develop around the use of veils.

They are inspired by artists and celebrities who wear veils whom they access through their Youtube channels. Then they experiment veils through the process, starting from wearing a long veil, using masks, and applying face veils (cadar). Likewise, modern facilities supported by the development of information and technology have enabled them to access the teachings about Islam from Islamic populism groups, which skilfully and systematically use the media to convey their invitations and influences.

The debate among families is always the initial challenge of the decision. Then there is discussion and reflection, which results in the understanding and agreement of parents and the nuclear family in the decision to wear the veil. Meanwhile, in the social and friendship environment, the challenge and support as well.

A general tendency can be drawn from their profiles that the family environment influences their decision less significant than that of friends. Only two informants admitted that their families did go into religion but did not direct the veil. Two people have not received permission from their parents. They all decided to veil in the last five years. Some have started in year one, some have started year two and three of their university education. Having friends who can bring goodness to them is a gift.

\section{Affirming Identity and Strengthening Literacy}

Migrating or changing (hijrah) is easy, but consistency (istiqāmah) is difficult. Self-perception to be an ideal woman that is formed from the learning process and social interaction often experiences dynamics and struggles. They often find contradictions with what they believe and practice. The most crucial factor is the clash of perceptions between them and those who do not wear veils. For them, their choice of such fashion style, obviously, is part of the effort to get the title of a good person, to be Muslims who obey their norms. But for others, such a style of dress is questionable, even is executed as symptoms of religious radicalism. Following is Aini's and Fatma's confession about it:

I do not have a problem with family, but from the wider community, there are still obstacles. They said "you are, like a terrorist. "Challenges also come from 
friends and colleagues who are not wearing veils, they like to say "alim (too pious)".40

Families usually support by saying "don't ever think about others." Many friends can also support in this journey, persistence and perseverance (istiqomah)should be there, because changing (hijrah) is easy but istiqomah is difficult. 41

Regarding the choice of wearing the veil, they carry out internal reinforcement after going through formative periods into the formation of their identities as devout Muslim women. They strengthen their beliefs by reading a lot, following recitation, or discussing with friends of the same visions and beliefs that it would be good to wear a veil. They also carry out external communication, which is socialization by trying to get along openly with colleagues from the wider social environment.

This period of reinforcement is determined whether the veil they use is merely a medium to self-improvement in developing their conservative, fundamental, and even Islamist ideology or moderate, progressive, or liberal position. Their decision really depends on which group offers intense, attractive, and articulative studies and discussions aggressively.

The way they communicate to the general audience that their choices are right and good is "silence" while showing a good attitude as evidence. This style is considered more effective in breaking public views who like to execute them. This is also what they refer to as istiqāmah, which is unified between the attitude of the heart and deeds. For them, challenges must be responded to in a wise manner and proper attitude. And the "silence" proved to have melted many people who had been vehemently opposed to their veils.

The next strategy is "speak out" mode. So besides being silent, they must also be able to vocalize their views, that is, speak well and be useful, so that others can also learn. To the public, they also show that they understand religious concepts and being on the way of learning more and becoming better. With a package of responses to challenges like this, they want to show that their choice of religious style is a dynamic process that is continually being improved because veiling is not an identity for spiritual perfection.

\footnotetext{
${ }^{40}$ Interview with J. Aini., female student of Universitas Islam Negeri Mataram, April 25, 2019.

41 Interview with Fatma L., female student of Universitas Islam Negeri Mataram, April 26, 2019.
} 


\section{Looking at Indonesia Behind the Veil}

A further derivation of the view that women are determinants of the condition of the country is that they should actively participate in making Indonesia better and love his country wholeheartedly. Interestingly, some of those who actively participated in BMIC recitation (groups made by ex-HTI), for example, had different views from HTI who wanted Islamic based state (khilafah). Indeed, two of those who admitted that they departed from a family background affiliated with the Muhammadiyah and NU organizations had a more conservative view when they say, "Indonesia is not ideal as the basis of the state is not religion." But in general, they see Indonesia and its diversity and governance system as an ideal choice.

Their view of Indonesia can be categorized into three types, namely: First, Indonesia is ideal. Based on Pancasila's first precepts, The Oneness of God and Religiosity, practicing religion are not restricted. Multiculturalism is a part of reality that must be addressed wisely. Associating with different people, religions, and ethnic groups is for the nation's solidarity. But each religious adherent needs to follow the teachings of their faith and strengthen their own identity without disturbing or excluding each other. The majority need to model good things without any truth claims.

The above views represent their majority of 12 people from informants. They see that as the majority, Muslims need to do things better to inspire others and to keep the minority feel safe. Pancasila should protect all citizens by practicing their faiths in Indonesia. This view is a social capital that needs to be cultivated among young people. It is interesting to find this view raised by veiled students who have been suspected of being contaminated with various national movements, which tend to be Islamist and radical.

Some of these informants were actively involved in becoming peace ambassadors in cyberspace, activists of women's empowerment in the issue of religion-based violence. The veil that they use gives color to the dynamics of these movements, and they take advantage of the opportunity also to improve the image of the veil in the eyes of the public.

Second, Indonesia is not a religious country because it does not apply Islamic law. The government is not seriously upholding Islam as the basis for Muslim life. Multiculturalism must be adapted to religion. Culture must follow 
religion and not vice versa. The main foundation of life must be based on the Qur'an and al-Hadith, which have comprehensive regulations, and there is no need to join religious organizations.

This view was shared by two informants. They do not clearly say Indonesia is ideal or not, but they tend to claim that Indonesia is not a religious country, and religion here is only simplified as Islam. Their attitude of exclusiveness is evident, for example, by focusing on all aspects of state and nation on religion. They also do not want to be in a religious organization because religion does not need other patches, only Islam. This group also saw the purity of knowledge of a teacher that should be followed are those who came from Islamic Studies in the Middle East while the moderate group is a group whose knowledge is mixed

Third, one of the informants stated Indonesia is not ideal because justice has not been upheld. She does not base the ideals of a country on what system is used but rather on whether justice is obtained by all citizens without exception. She prefers to see the relation between state and religion in reciprocal ways in which both of them need to work cooperatively in achieving their shared-goals, which is to provide justice for all humankind.

\section{Conclusion}

There is an ambiguity regarding the concept of women's self-image in the view of veiled female students. They see women as "slander" (fitnah) and put a great responsibility on the morality of life on women's shoulders. At the same time, they also see the vital role of women for the progress of the nation and state, not only through domestic roles but also social activities. They use this veil to maintain these views while facilitating themselves to reject the consequences of marginalizing women based on the "slander" principle from public activities.

This ambiguity also occurs in other aspects related to the choice of wearing this veil, rejecting modernization, which, according to them, is considered as a source of moral degradation. At the same time, they accept and even use technology as a consequence of modernization, for example, internet technology and social media that allow them to continue to improve themselves through the propaganda of Islamic populist groups and Islamic transnationalism movement. 
Face veil thus becomes an arena of identity and ideology contestation for female students in which the circumstances of veiling is not only personal but also political. For example, they use the veil as a medium to maintain privacy while attracting attention. They also play their agency in the fight against persecution directed at them through literacy strengthening.

The process of strengthening literacy is a very influential agenda and moment to steer the further direction of where their ideology and identity will actually be strongly established. During their formative years, their identity and ideology are still dynamic and open. This is where the significance and contribution of this research to the discussion of the veil among female students can be claimed. That is to propose to progressive and moderate groups on the importance of presenting ways and content of Islamic propaganda that are more creative, engaging, fun, and intense as alternative 'dishes' for millennials in the process of strengthening or establishing their identity and ideology.

Meanwhile, the narrative of their nationalism in general is still coloured by tolerant and inclusive views, although it is also worth noting the tendency of exclusivism and conservatism of a small part of them. Indonesia behind the veil still holds a hope for a better future than the worries drawn from the excessive stigma associated with veils and radicalism.

This study also supports previous findings which explain that there is no single attitude or meaning to the veil, but it is varied and also as a media to play the agency. Thus the "veil" alone is not a deadly weapon of the hopes of moderateness. Many factors that lead to the ideology of veil wearer including how strong the progressive group vis a vis conservative play a way determine where these veiled-female search for identity anchored.[s]

\section{References}

Andiko, Toha. "Larangan Bercadar di Perguruan Tinggi Perspektif Sadd al-Dzariah." Madania: Jurnal Kajian Keislaman 22, no. 1 (2018): 113. https://doi.org/ 10.29300/madania.v22i1.993.

Bruinessen, Martin van. "Introduction: Contemporary Developments in Indonesian Islam and the 'Conservative Turn' of the Early Twenty-First Century." In Contemporary Developments in Indonesian Islam: Explaining the Conservative Turn, 1-20. Singapore: Iseas, 2013. 
al-Chaidar. "Konservatisme Islam di Indonesia (Antara Fundamentalisme dan Radikalisme)." Serambinews.Com, May 21, 2018. https://aceh.tribunnews. com/2018/05/21/konservatisme-islam-di-indonesia-antarafundamentalisme-dan-radikalisme?page $=2$.

Creswell, John W. Research Design: Qualitative and Quantitative Approach. New Delhi: Sage Publications, 1994.

Cuff, E. C., A. J. Dennis, D. W. Francis, and W. W. Sharrock. Perspectives in Sociology. London: Routledge, 2015. https://doi.org/10.4324/9781315761053.

Dzuhayatin, Ruhaini. "Feminism, Religious Moderation, and Radicalism." In The First Annual Conference on Gender and Social Movement (ACGSM). Jakarta: UIN Syarif Hidayatullah, 2019.

Guindi, Fadwa El. Jilbab: Antara Kesalehan, Kesopanan, dan Perlawanan. Translated by Mujiburrahman. Jakarta: Serambi, 2004.

Juneman. Psychology of Fashion: Fenomena Perempuan (Melepas) Jilbab. Yogyakarta: LKiS Pelangi Aksara, 2010.

Khoiroh, Lailatul, and Sulkhan Chakim. "Kuasa Perempuan Bercadar dalam Novel Akulah Istri Teroris Karya Abidah El Khalieqy (Analisis Wacana Teun A. Van Dijk)." Komunika: Jurnal Dakwah dan Komunikasi 10, no. 2 (1970): 292-309. https://doi.org/10.24090/komunika.v10i2.950.

Lies Marcoes-Natsir. Kesaksian Para Pengabdi: Kajian tentang Perempuan dan Fundamentalisme di Indonesia. Jakarta: Rumah Kitab, 2014.

Lyncoln, Yvonna S., and Egon G. Guba. Naturalistic Inquiry. London: Sage Publications, 1985.

MacLeod, Arlene Elowe. Accommodating Protest: Working Women, the New Veiling, and Change in Cairo. New York: Columbia University Press, 1991.

Nisa, Eva Fahrun. "Embodying the True Islam: Face Veiled-Women in Contemporary Indonesia." Australian National University, 2011. https://doi.org/10.25911/5d7788f8e8499.

Reinharz, Shulamith. Feminist Methods in Social Research. Oxford: Oxford University Press, 1992.

Ritzer, George. Contemporary Sociological Theory. New York: Alfred A. Knop, 1988.

Rofi'ah, Nur. "Qirā'ah Mubādalah sebagai Syarat Tafsir Agama Adil Gender (Pengantar)." In Qirā'ah Mubādalah: Tafsir Progresif untuk Keadilan Gender 
dalam Islam, edited by Faqihuddin Abdul Kodir. Yogyakarta: IRCISOD, 2019.

Smith, Jonathan A. Qualitative Psychology: A Practical Guide to Research Method. Los Angeles: Sage Publications, 2009.

Sunesti, Yuyun, Noorhaidi Hasan, and Muhammad Najib Azca. "Young Salafi-Niqabi and Hijrah: Agency and Identity Negotiation." Indonesian Journal of Islam and Muslim Societies 8, no. 2 (2018): 173-98. https://doi.org/10.18326/ ijims.v8i2.173-198.

Syafii, Imam. "Di Balik Cadar Ada Radikalisme." Alif.Id, March 8, 2018. https://alif.id/read/muhammad-syafii/di-balik-cadar-ada-radikalismeb207541p/.

Wahib, Ahmad Bunyan. "Being Pious among Indonesian Salafists." Al-Jami'ah: Journal of Islamic Studies 55, no. 1 (2017): 1-26. https://doi.org/10.14421/ ajis.2017.551.1-26. 
This page itentionaly left blank. 